\title{
Faktor-Faktor Yang Mempengaruhi Status Gizi Anak Balita Di Desa Loyang Wilayah Kerja Puskesmas Cikedung Kabupaten Indramayu Tahun 2018
}

\section{The factors that influences the nutritional status of children under five in Loyang village region in the Cikedung Community Health Centre 2018}

\section{Turyati $^{1}$, Tayong Siti Nurbaeti ${ }^{2}$}

${ }^{1}$ Program Studi Kesehatan Masyarakat, FKM UNWIR, Indramayu

e-mail: ${ }^{1}$ mamahyati102@yahoo.com, ${ }^{2}$ t.siti.nurbaeti@gmail.com

\begin{abstract}
Abstrak
Latar Belakang Gizi merupakan salah satu penentu kualitas sumber daya manusia. Akibat kekurangan gizi akan menyebabkan beberapa efek serius seperti kegagalan pertumbuhan fisik serta tidak optimalnya perkembangan dan kecerdasan. Akibat lain adalah terjadinya penurunan produktivitas, menurunnya daya tahan tubuh terhadap penyakit yang akan meningkatkan resiko kesakitan dan kematian. Metoda Penelitian menggunakan survey analitik dengan pendekatan cross sectional populasi berjumlah 571 , maka sampel untuk penelitian ini adalah sebanyak 85 balita di desa Loyang. Hasil Penelitian penelitian yang dilakukan dengan uji statistic menggunakan chi square didapatkan tidak ada hubungan pengetahuan, pendidikan, pendapatan dengan status gizi anak balita dengan nilai $p$ (value $)=$ $(0,369)(0,805)(0,753)>0,05$ dan ada hubungan pemberian ASI eksklusif dengan status gizi pada anak balita di desa Loyang dengan nilai $p($ value $)=0,001<0,05$. Saran Untuk penelitian selanjutnya diharapkan menjadi referensi dalam mengembangkan penelitian tentang pentingnya status gizi.
\end{abstract}

Kata kunci : Pengetahuan, Pendidikan, Pendapatan, Pemberian ASI Eksklusif Status Gizi

\footnotetext{
Abstract

Background Nutrition is one of the determinants of the quality of human resources. Due to malnutrition will cause some serious effects such as failure of physical growth and not optimal development and intelligence. Another result is a decrease in productivity, a decrease in the body's resistance to diseases that will increase the risk of illness and death. Research Methods By using an analytical survey with a cross sectional approach of the population amounting to 571, so the sample for this research as many 85 todllers in Loyang village. Research Result Research to be done by using statistical test chi square that found no relationship with knowledge, education, income with nutrition status of the chilrdren under five with a value $p$ (value $)=(0.369)(0.805)(0.753)>0,05$ and there is a relationship of exclusive breastfeeding (ASI) with nutrition status in chilrdren under five in Loyang village with a value of $p($ value $)=0.001<0.05$.
}

Suggestion For furthur research is expected to be reference in developing to the research on the importance of nutritional status.

Keywords: Knowledge, education, income, giving exclusive breastfeeding with nutrition status.

\section{Pendahuluan}

Menurut WHO diperkirakan terdapat anak-anak usia di bawah 5 tahun dengan kasus status gizi pendek sebanyak 155 juta jiwa atau $23 \%$ dan 52 juta jiwa dengan status gizi kurus. Dari jumlah 52 juta jiwa status gizi kurus terdapat sebanyak 17 juta jiwa dengan kasus gizi buruk. ${ }^{1}$ Prevalensi status gizi balita di Indonesia menurut indeks $\mathrm{BB} / \mathrm{U}$, didapatkan hasil: $79,7 \%$ gizi baik, 14,9\% gizi kurang, $3,8 \%$ gizi buruk, dan $1,5 \%$ gizi lebih. Status gizi balita menurut indeks $\mathrm{TB} / \mathrm{U}$, didapatkan hasil: $71 \%$ normal dan $29,9 \%$ balita pendek dan sangat pendek. Status gizi balita menurut indeks $\mathrm{BB} / \mathrm{TB}$, didapatkan hasil $82,7 \%$ status gizi normal, $8,2 \%$ kurus, 5,3\% gemuk dan $3,7 \%$ sangat kurus. ${ }^{2}$

Indikator utama derajat kesehatan masyarakat adalah angka kematian bayi (AKB) atau Infant Mortality Rate (IMR). Menurut data Survey Demografi dan Kesehatan Indonesia (SDKI) 2007, AKB 34 per 1.000 kelahiran hidup, Angka Kematian Neonatus (AKN) 19 per 1.000 kelahiran hidup dan Angka Kematian Balita (AKABA) 44 perkelahiran hidup. ${ }^{2}$ Dari hasil penelitian yang ada, angka kematian bayi ini tidak berdiri sendiri, melainkan terkait dengan faktor-faktor 
lain, terutama gizi. Status gizi ibu pada waktu melahirkan, dan gizi bayi itu sendiri sebagai faktor tidak langsung maupun langsung sebagai penyebab kematian bayi.Penyakit diare dan pneumonia pada bayi yang merupakan penyakit pembunuh (killing diseases) utama bayi dan anak balita ternyata juga berkaitan dengan gizi buruk pada bayi dan anak balita tersebut.Bayi atau anak balita yang kekurangan gizi sangat rentan terhadap penyakit-penyakit infeksi, termasuk diare dan infeksi saluran akut, utamanya pneumonia.Oleh sebab itu, perbaikan gizi masyarakat yang difokuskan pada perbaikan bayi dan anak balita merupakan awal dalam meningkatkan derajat kesehatan masyarakat. Sebaliknya, kekurangan gizi pada bayi akan berakibat terhadap munculnya masalah kesehatan yang lain, dan akhirnya akan berdampak terhadap menurunnya derajat kesehatan masyarakat . ${ }^{3}$

Menurut penelitian Nency, adanya hubungan pengetahuan ibu, tingkat pendidikan, pola asuh terhadap kejadian gizi kurang di Puskesmas Glugur. ${ }^{4}$ Menurut penelitian Ali, pendapatan dapat mempengaruhi pola konsumsi suatu keluarga. ${ }^{5}$ Hasil Riset Kesehatan Dasar menunjukkan prevalensi gizi kurang pada balita $(\mathrm{BB} / \mathrm{U}<-$ 2SD) memberikan gambaran yang fluktuatif dari 18,4\% tahun 2007 menurun menjadi $17,9 \%$ tahun 2010 kemudian meningkat menjadi $19,6 \%$ tahun 2013. Perubahan terutama pada prevalensi gizi buruk, yaitu dari $5,4 \%$ pada tahun $2007,4,9 \%$ pada tahun 2010 , dan $5,7 \%$ pada tahun 2013. Hal ini menunjukkan bahwa setiap tahun selama periode 2010-2013 ada peningkatan jumlah balita gizi kurang dan gizi buruk. ${ }^{2}$

Jumlah balita gizi kurang dan gizi sangat kurang dari 7 desa tertinggi di desa Loyang yaitu sebanyak 118 balita gizi kurang dengan presentasi $20,7 \%$ dari 571 jumlah balita seluruhnya di desa Loyang ,yang berarti prevalensi desa Loyang sudah termasuk ke prevalensi yang dianggap serius karena sudah melebihi $20 \%$ sesuai dengan standar WHO dan pada tahun 2017 desa Loyang yang berstatus gizi kurang ada 20,9\% yang artinya ada 127 balita gizi kurang dari 607 balita di desa Loyang, dimana masalah kesehatan dianggap serius bila prevalensi gizi buruk-kurang antara 20,0-29,0\% dan dianggap prevalensi sangat tinggi bila $\geq 30 \%$. ${ }^{1}$

Dengan melihat permasalahan tersebut penulis tertarik untuk melakukan penelitian mengenai faktor-faktor yang mempengaruhi status gizi anak balita di desa Loyang wilayah kerja Puskesmas Cikedung kabupaten Indramayu tahun $2018 .^{6}$

\section{Metode}

Jenis penelitian yang digunakan dalam penelitian ini adalah metode observasional analitik dengan pendekatan studi cross sectional .Pengambilan sampel dilakukan secara random sampling.Populasi dalam penelitian ini adalah seluruh balita di desa Loyang wilayah kerja Puskesmas Cikedung tahun 2018 yang berjumlah 571 balita. Sampel pada penelitian ini adalah 85 balita. Analisis bivariat, yaitu untuk melihat kemaknaan hubungan antara variable bebas (independent) dengan variable terikat (dependent) dengan menggunakan uji statistic chi-square $\left(\mathrm{X}^{2}\right)$ dengan derajat kemaknaan 0,05 .

\section{Hasil}

Tabel 1. Distribusi Frekuensi Pengetahuan Ibu Balita Di Desa Loyang Wilayah Kerja Puskesmas Cikedung tahun 2018

\begin{tabular}{lcc}
\hline Pengetahuan & Frekuensi & Presentasi \\
\hline Kurang & 13 & 15,3 \\
\hline Baik & 72 & 84,7 \\
\hline \multicolumn{1}{c}{ Jumlah } & 85 & 100 \\
\hline
\end{tabular}

Berdasarkan tabel 1 dapat diketahui responden yang berpengatahuan kurang yaitu 13 orang $(15,3 \%)$ dan responden yang berpengetahuan baik yaitu 72 orang $(84,7 \%)$. 
Tabel 2. Distribusi Frekuensi Pendapatan

Keluarga di Desa Loyang Wilayah Kerja Puskesmas Cikedung Tahun 2018

\begin{tabular}{lcc}
\hline Pendapatan & Frekuensi & Presentasi \\
\hline Rendah & 52 & 61,2 \\
\hline Tinggi & 33 & 38,8 \\
\hline \multicolumn{1}{c}{ Jumlah } & 85 & 100 \\
\hline
\end{tabular}

Berdasarkan tabel 2 dapat diketahui responden yang pendidikannya rendah (SD) yaitu 54 orang $(63,5 \%)$ dan responden yang berpendidikan tinggi yaitu 31 orang $(36,5 \%)$.

Tabel 3. Distribusi Frekuensi Pemberian ASI Eksklusif di Desa Loyang Wilayah Kerja Puskesmas Cikedung Tahun 2018 Pemberian Frekuensi Presentasi ASI

\begin{tabular}{lcc}
\hline Tidak ASI & 62 & 72,9 \\
Eksklusif & & \\
\hline ASI & 23 & 27,1 \\
Eksklusif & & \\
\hline \multicolumn{1}{c}{ Jumlah } & 85 & 100 \\
\hline
\end{tabular}

Berdasarkan tabel 3 dapat diketahui responden yang tidak ASI eksklusif yaitu 62 orang $(72,9 \%)$ dan responden yang ASI eksklusif yaitu 23 orang $(27,1 \%)$

Tabel 4 Distribusi Frekuensi Status Gizi Di Desa Loyang Wilayah Kerja Puskesmas Cikedung Tahun 2018

\begin{tabular}{lcc}
\hline Status Gizi & Frekuensi & Presentasi \\
\hline Kurang & 52 & 61,2 \\
\hline Baik & 33 & 38,8 \\
\hline Jumlah & 85 & 100 \\
\hline
\end{tabular}

Berdasarkan tabel 4 terdapat 52 balita (62\%) yang terkena gizi kurang dan 33 balita $(38,8 \%)$ yang gizi baik di desa Loyang wilayah kerja Puskesmas Cikedung tahun 2018.

Tabel 5. Hubungan Antara Pengetahuan Ibu Balita dengan Satus Gizi Anak Balita

\begin{tabular}{|c|c|c|c|c|c|c|c|}
\hline \multirow{3}{*}{ Pengetahuan } & \multicolumn{4}{|c|}{ Status Gizi } & \multicolumn{2}{|c|}{ Jumlah } & \multirow[t]{3}{*}{$\begin{array}{c}\mathbf{P} \\
\text { Value } \\
\end{array}$} \\
\hline & \multicolumn{2}{|c|}{ Kurang } & \multicolumn{2}{|c|}{ Baik } & \multirow[b]{2}{*}{$\mathbf{N}$} & \multirow[b]{2}{*}{$\%$} & \\
\hline & $\mathbf{N}$ & $\%$ & $\mathbf{N}$ & $\%$ & & & \\
\hline Kurang & 6 & 46,2 & 7 & 53,8 & 13 & 100 & \multirow[t]{3}{*}{0,369} \\
\hline Baik & 46 & 63,9 & 26 & 36,1 & 72 & 100 & \\
\hline Jumlah & 52 & 61,2 & 33 & 38,8 & 85 & 100 & \\
\hline
\end{tabular}

Berdasarkan tabel 5 diperoleh nilai $P$ (value $)=0,369$ pada $\alpha=0,05$ karena nilai $p$ (value) 0,369>0,05. Maka kesimpulan dari hasil uji chi square tersebut menunjukan bahwa ho (hipoesa nol gagal tolak) artinya tidak ada hubungan antara pengetahuan ibu balita dengan status gizi balita di desa Loyang wilayah kerja Puskesmas Cikedung tahun 2018. telah mapan; dan (5) memunculkan teori-teori baru atau modifikasi teori yang telah ada. 
Tabel 6. Hubungan Antara Pendidikan Ibu Balita dengan Status Gizi Pada Balita

\begin{tabular}{|c|c|c|c|c|c|c|c|}
\hline \multirow{3}{*}{ Pendidikan } & \multicolumn{4}{|c|}{ Status Gizi } & \multicolumn{2}{|c|}{ Jumlah } & $\begin{array}{c}\mathbf{P} \\
\text { Value }\end{array}$ \\
\hline & \multicolumn{2}{|c|}{ Kurang } & \multicolumn{2}{|c|}{ Baik } & \multirow[t]{2}{*}{$\mathbf{N}$} & \multirow[t]{2}{*}{$\%$} & \multirow{5}{*}{0,805} \\
\hline & $\mathbf{N}$ & $\%$ & $\mathbf{N}$ & $\%$ & & & \\
\hline Rendah & 32 & 59,3 & 22 & 53,8 & 54 & 100 & \\
\hline Tinggi & 20 & 64,5 & 11 & 36,1 & 31 & 100 & \\
\hline Jumlah & 52 & 61,2 & 33 & 38,8 & 85 & 100 & \\
\hline
\end{tabular}

Berdasarkan tabel 6 diperoleh nilai $P$ (value $)=0,369$ pada $\alpha=0,05$ karena nilai $p$ (value) $0,805>0,05$. Maka kesimpulan dari hasil uji chi square tersebut menunjukan bahwa ho (hipoesa nol gagal tolak) artinya tidak ada hubungan antara pendidikan ibu balita dengan status gizi anak balita di desa Loyang wilayah kerja Puskesmas Cikedung tahun 2018.

Tabel 7. Hubungan Antara Pendapatan Dengan Status Gizi Anak Balita

\begin{tabular}{|c|c|c|c|c|c|c|c|}
\hline \multirow{3}{*}{ Pengetahuan } & \multicolumn{4}{|c|}{ Status Gizi } & \multicolumn{2}{|c|}{ Jumlah } & $\begin{array}{c}\mathbf{P} \\
\text { Value }\end{array}$ \\
\hline & \multicolumn{2}{|c|}{ Kurang } & \multicolumn{2}{|c|}{ Baik } & \multirow[t]{2}{*}{$\mathbf{N}$} & \multirow[t]{2}{*}{$\%$} & \multirow{5}{*}{0,753} \\
\hline & $\mathbf{N}$ & $\%$ & $\mathbf{N}$ & $\%$ & & & \\
\hline Rendah & 33 & 63,5 & 19 & 36,5 & 52 & 100 & \\
\hline Tinggi & 19 & 57,6 & 14 & 42,4 & 33 & 100 & \\
\hline Total & 52 & 61,2 & 33 & 38,8 & 85 & 100 & \\
\hline
\end{tabular}

Berdasarkan tabel 7 diperoleh nilai $P$ (value $)=0,753$ pada $\alpha=0,05$ karena nilai $p$ (value) 0,753 > 0,05. Maka kesimpulan dari hasil uji chi square tersebut menunjukan bahwa ho (hipoesa nol gagal tolak) artinya tidak ada hubungan antara pendapatan ibu balita dengan status gizi anak balita di desa Loyang wilayah kerja Puskesmas Cikedung tahun 2018.

Tabel 8. Hubungan Pemberian ASI Eksklusif Dengan Status Gizi Anak Balita

\begin{tabular}{|c|c|c|c|c|c|c|c|}
\hline \multirow{3}{*}{ Pengetahuan } & \multicolumn{4}{|c|}{ Status Gizi } & \multicolumn{2}{|c|}{ Jumlah } & \multirow{3}{*}{$\begin{array}{c}\begin{array}{c}\mathbf{P} \\
\text { Value }\end{array} \\
0,001\end{array}$} \\
\hline & \multicolumn{2}{|c|}{ Kurang } & \multicolumn{2}{|c|}{ Baik } & \multirow[t]{2}{*}{$\mathbf{N}$} & \multirow[t]{2}{*}{$\%$} & \\
\hline & $\mathbf{N}$ & $\%$ & $\mathbf{N}$ & $\%$ & & & \\
\hline $\begin{array}{l}\text { Tidak ASI } \\
\text { eksklusif }\end{array}$ & 45 & 72,6 & 17 & 27,4 & 62 & 100 & \\
\hline $\begin{array}{l}\text { ASI } \\
\text { Eksklusif }\end{array}$ & 7 & 30,4 & 16 & 69,6 & 23 & 100 & \\
\hline Total & 52 & 61,2 & 33 & 38,8 & 85 & 100 & \\
\hline
\end{tabular}


Berdasarkan tabel 8 diperoleh nilai $P$ $($ value $)=0,001$ pada $\alpha=0,05$ karena nilai $p$ (value) 0,001 > 0,05. Maka kesimpulan dari hasil uji chi square tersebut menunjukan bahwa ho (hipotesa nol ditolak) artinya ada hubungan antara pemberian ASI eksklusif dengan status gizi anak balita di desa Loyang wilayah kerja Puskesmas Cikedung tahun 2018.

\section{Pembahasan}

\section{Faktor Pengetahuan dengan Status Gizi Pada Balita}

Berdasarkan hasil penelitian diperoleh nilai $P$ (value $)=0,369$ pada $\alpha=0,05$ karena nilai $p$ (value) $0,369>0,05$. Maka kesimpulan dari hasil uji chi square tersebut menunjukan bahwa ho (hipoesa nol gagal tolak) artinya tidak ada hubungan antara pengetahuan ibu balita dengan status gizi balita di desa Loyang wilayah kerja Puskesmas Cikedung tahun 2018. Walaupun pengetahuan ibu balita sudah baik tidak serta merta mempengaruhi status gizi balita.

Pengetahuan atau kognitif merupakan domain yang sangat penting untuk terbentuknya tindakan seseorang (overt behavior). Kurangnya pengetahuan tentang gizi maka kemampuan untuk menerapkan informasi dalam kehidupan sehari-hari merupakan penyebab kejadian gangguan kurang gizi. ${ }^{7}$

Pengetahuan gizi dipengaruhi oleh berbagai faktor, disamping pendidikan yang pernah dijalani, faktor lingkungan sosial dan frekuensi kontak dengan media massa juga mempengaruhi pengetahuan gizi. Salah satu penyebab gangguan gizi adalah kurangnya pengetahuan gizi atau kemauan untuk menerapkan informasi tentang gizi dalam kehidupan sehari-hari. Perilaku ibu ditentukan oleh pengetahuannya mengenai suatu hal, sebagian besar ibu memiliki pengetahuan baik dengan status gizi balita normal dan sebagian memiliki pengetahuan yang kurang. Tingkat pengetahuan ibu tentang gizi yang tinggi dapat mempengaruhi pola makan balita dan akhirnya akan mempengaruhi status gizi balita. Jika pengetahuan ibu baik maka ibu dapat memilih dan memberikan makan bagi balita baik dari segi kualitas maupun kuantitas yang dapat memenuhi angka kecukupan gizi yang dibutuhkan oleh balita sehingga dapat mempengaruhi status gizi balita tersebut. Penelitian ini berarti tidak selaras dengan tinjauan teori karena ada faktor lain yang mempengaruhi status gizi. ${ }^{8}$

Pengetahuan akan memudahkan seseorang untuk menyerap informasi dan mengimplementasikannya dalam perilaku dan gaya hidup sehari-hari. Faktor-faktor yang mempengaruhi pengetahuan yaitu umur, pendidikan, dan pengalaman. Semakin cukup umur, tingkat pematangan dan kekuatan seseorang akan lebih matang dalam berfikir, belajar, dan bekerja sehingga pengetahuan pun akan bertambah. ${ }^{9}$ Pengetahuan gizi kerap dipengaruhi oleh tingkat pendidikan yang berdampak pada peran dalam penyusunan makan keluarga, serta pengasuhan dan perawatan anak. Hasil penelitian tersebut sesuai dengan penelitian yang dilakukan oleh Devi yang menyatakan bahwa dari 1200 terdapat 582 (49\%) dengan masalah gizi kurang. ${ }^{10}$ Masalah gizi pada anak ini disebabkan oleh berbagai penyebab, salah satu penyebab masalah gizi pada anak ialah akibat konsumsi makanan yang tidak baik, sehingga energi yang masuk dan keluar tidak seimbang. Tubuh memerlukan pemilihan makanan yang baik agar kebutuhan zat gizi terpenuhi dan fungsi tubuh berjalan dengan baik. ${ }^{9}$

Penelitian ini sejalan dengan penelitian sebelumnya oleh Asriani, Andi fajriansi, sumira tentang hubungan antara Pola Asuh, pengetahuan, dan sikap orangtua terhadap status gizi balita di Kelurahan Lampa Kecamatan Duampanua kabupaten Pinrang yang dilakukan pada 74 responden menyatakan bahwa pengetahuan gizi ibu dengan status gizi balita mempunyai nilai $\mathrm{p}$ 0,416 sehingga tidak ada hubungan yang 
bermakna antara pengetahuan gizi ibu dengan status gizi balita mempunyai nilai $p$ 0,416 sehingga tidak ada hubungan yang bermakna antara pengetahuan gizi ibu dengan status gizi balita. Hal ini juga sejalan dengan penelitian yang dilakukan oleh Mahardika mengenai hubungan antara pendapatan keluarga dan pengetahuan gizi ibu dengan status gizi balita di desa Selodoko kecamatan Ampel kabupaten Boyolali yang menyatakan bahwa pengetahuan gizi ibu dengan status gizi balita mempunyai nilai $\mathrm{p}=0,110$ sehingga tidak ada hubungan antara pengetahuan ibu dengan status gizi balita. ${ }^{11}$

Penelitian ini tidak sesuai dengan penelitian yang dilakukan Susanti,Indrianti dan Utomo tentang hubungan pengetahuan ibu tentang gizi dengan status gizi anak umur 1-3 tahun pada 98 responden di wilayah kerja Puskesmas Rojosari yang menyatakan bahwa terdapat hubungan bermakna antara pengetahuan ibu tentang gizi dengan status gizi anak umur 1-3 tahun (nila p 0,004). ${ }^{12}$

Keadaan ini bisa juga disebabkan karena pengetahuan merupakan penyebab tidak langsung gangguan gizi pada balita, masih ada factor langsung seperti pola konsumsi, penyakit infeksi, faktor sosial dan ekonomi. Kecukupan pangan di tingkat keluarga belum tentu menjamin perbaikan status gizi setiap individu anggotanyaapabila tidak disertai dengan pengetahuan dan kemampuan mengolah makanan dan cara pemberian makanan pada anak meskipun bahan makanan sudah tersedia. ${ }^{11}$

\section{Faktor Pendidikan dengan Status Gizi Anak Balita}

Berdasarkan hasil penelitian diperoleh nilai $P$ (value $)=0,369$ pada $\alpha=0,05$ karena nilai $p$ (value) $0,805>0,05$. Maka kesimpulan dari hasil uji chi square tersebut menunjukan bahwa ho (hipotesa nol gagal tolak) artinya tidak ada hubungan antara pendidikan ibu balita dengan status giz anak balita di desa Loyang wilayah kerja Puskesmas Cikedung tahun 2018.

Hasil penelitian ini tidak sesuai dengan teori yang dipaparkan dalam literatur yang dibahas di awal, dimana pada teori tersebut digambarkan terdapat hubungan antara faktor pendidikan yang di dapat orang tua secara formal dengan status gizi balita. Hal ini bisa terjadi karena beberapa dugaan, misalnya para orangtua yang berpendidikan itu tidak memahami betul bagaimana cara menerapkan apa yang di dapatnya di bangku sekolah sehingga tidak memungkinkan menerapkan pola asuh yang salah kepada balitanya yang berakibat menurunnya status gizi pada anak balita. Atau karena adanya pengaruh lain seperti budaya yang dianut oleh para nenek moyang yang mengajarkan suatu kebiasaan yang sukar di cerna oleh akal sehat, orang yang berpendidikan tinggi belum tentu percaya akan adat istiadat (pantangan akan suatau makanan atau keharusan memakan suatu makanan), sehingga dia tidak menuruti apa yang menjadi adat tersebut. Dan orang berpendidikan rendah pun banyak yang sudah mengerti akan tata cara memberikan makanan yang baik untuk anaknya itu di dasarkan pada pengalamannya sebelumnya. ${ }^{13}$

Hal ini sesuai dengan penelitian yang dilakukan oleh Astuti dan Taurina yang menyatakan bahwa tidak ada hubungan antara tingkat pendidikan ibu dengan status gizi anak pra sekolah dan sekolah dasar di kecamatan Godean berdasarkan indeks BB/TB) taurina 2012. Dari hasil uji chi square pada penelitian ini didapatkan status gizi berdasarkan berat badan/ umur tidak ada hubungan dengan tingkat pendidikan ayah karena nilai $p=0,19$ ( $p>0,05$. Hal ini sesuai dengan penelitian suryadi (2009) yang mengemukakan tidak ada hubungan antara tingkat pendidikan ayah dengan status gizi balita dan ada hubungan tingkat pendidikan ibu karena nilai $p=0,02$ $(p<0,05) .{ }^{14}$ Begitu juga hasil penelitian lain yang menunjukan bahwa ada hubungan signifikan pendidikan ibu dengan status gizi balita.$^{15}$ 


\section{Faktor Pendapatan Keluarga Dengan Status Gizi Anak Balita}

Berdasarkan hasil penelitian diperoleh nilai $P$ (value $)=0,753$ pada $\alpha=0,05$ karena nilai $p$ (value) $0,753>0,05$. Maka kesimpulan dari hasil uji chi square tersebut menunjukan bahwa ho (hipoesa nol gagal tolak) artinya tidak ada hubungan antara pendapatan ibu balita dengan status gizi anak balita di desa Loyang wilayah kerja Puskesmas Cikedung tahun 2018.

Pemenuhan gizi yang baik didukung dengan tingkat pendapatan yang memadai. Pendapatan keluarga atau status ekonomi merupakan salah satu faktor yang berkaitan dengan terpenuhinya ketersediaan pangan didalam keluarga, karena daya beli keluarga sangat ditentukan oleh tingkat pendapatan keluarga.Ketersediaan pangan yang kurang menjadi salah satu penyebab terjadinya gizi kurang.Penelitian ini berarti tidak selaras dengan tinjauan teori yang menyatakan bahwa pendapatan berpengaruh terhadap status gizi.

Pendapatan keluarga yang rendah, akan mempengaruhi ketersediaan dan akses pan gan keluarga. Jika hal tersebut terjadi, maka secara tiding langsung pendapatan keluarga dapat mempengaruhi status gizi anggota keluarga khususnya balita karena asupan yang dikonsumsi tidak mencukupi atau tidak sesuai dengan kebutuhan.Keluarga yang memiliki pendapatan yang tinggi cenderung memiliki pengeluaran terhadap pangan yang besar jika dibandingkan dengan keluarga yang memiliki pendapatan rendah baik dari segi kualitas maupun kuantitas makanan tersebut. Namun, jika pendapatan suatu keluarga tinggi tapi pengetahuan ibu tentang gizi kurang maka pengeluaran terhadap pangan dalam keluarga tersebut hanya didasarkan pada pertimbangan selera tanpa mempertimbangkan kebutahan gizi balita tersebut. ${ }^{17}$

Dari hasil penelitian Puspasari Dan Andri hasil analisis menunjukan bahwa tidak ada hubungan antara pendapatan keluarga dengan status gizi balita $(\mathrm{BB} / \mathrm{U}),(\mathrm{p}=0,553) .{ }^{18}$

\section{Faktor Pemberian ASI Eksklusif Dengan Status Gizi Anak Balita}

Berdasarkan hasil penelitian diperoleh nilai $P$ (value $)=0,001$ pada $\alpha=0,05$ karena nilai $p$ (value) $0,001>0,05$. Maka kesimpulan dari hasil uji chi square tersebut menunjukan bahwa ho (hipoesa nol ditolak) artinya ada hubungan antara pemberian ASI eksklusif dengan status gizi anak balita di desa Loyang wilayah kerja Puskesmas Cikedung tahun 2018.

ASI adalah makanan bayi yang paling penting terutama pada bulan-bulan pertama kehidupan.ASI merupakan sumber gizi yang sangat ideal dengan komposisi yang sangat seimbang dan sesuai dengan kebutuhan pertumbuhan bayi karena ASI adalah makanan bayi yang paling sempurna, baik secara kualitas dan kuantitas. ASI sebagai makanan tunggal akan cukup memenuhi kebutuhan tumbuh kembang bayi. 6 bulan. ${ }^{19}$

Hal ini membuat beberapa organisasi seperti WHO (World Health Organization), UNICEF (United Nations Children's Fund), dan WHA (World Health Assembly) merekomendasikan pemberian ASI saja selama 6 bulan. Setelah itu bayi diberi makanan pendamping yang benar dan tepat sehingga ASI tetap diteruskan sampai usia 2 tahun atau lebih. Penelitian ini berarti selaras dengan tinjauan teori.Ada hubungan pemberian ASI eksklusif terhadap status gizi (Al-Rahmat 2013). Penelitian ini selaras Menurut M.Kurnia Widiastuti 2016 ada hubungan ASI eksklusif terhadap status gizi. ${ }^{20}$

Menurut M. Kurnia Widiastuti bahwa 9\% ibu yang tidak memberikan ASI Eksklusif memiliki balita dengan status gizi di atas garis merah dan 1,3\% memiliki status gizi dibawah garis merah, sedangkan $74,4 \%$ ibu yang memberikan ASI eksklusif memiliki balita dengan status gizi di atas garis merah dan $15,4 \%$ memiliki status gizi di bawah garis merah. Hasil uji korelasi nilai signifikansi $p=$ 
$0,000(p<0,05)$, sehingga di simpulkan ada hubungan antara pemberian ASI eksklusif dengan status gizi balita usia 6-24 bulan. ${ }^{21}$

Pemberian ASI eksklusif memiliki hubungan dengan kejadian gizi kurang pada balita. Hal ini ditunjukan dengan nilai signifikansi dari hasil pengolahan data didapatkan nilai sebesar 0,029 , nilai OR yaitu 7,034 artinya, anak yang berumur 1-5 tahun dengan pemberian ASI yang tidak eksklusif lebih beresiko akan mengalami gizi kurang 7 kali lipat. ${ }^{22}$

Hasil penelitian ini sejalan dengan penelitian yang menyatakan bahwa bayi 6-12 bulan yang mendapat ASI eksklusif beresiko 0,44 kali menderita gizi kurang disbanding dengan yang tidak mendapat ASI eksklusif 2,3 kali beresiko terkena gizi kurang. Penelitian ini menyebutkan bahwa bayi yang mendapat ASI eksklusif 0,3 kali beresiko menderita gizi kurang disbanding bayi yang tidak mendapatkan ASI eksklusif. Hasil penelitian di iatas secara umum menunjukan bahwa pemberian ASI eksklusif pada bayi selama 6 bulan pertama kehidupannya dapat mencegah gizi kurang. Secara teori hal itu beralasan dimana air susu ibu sangat penting untuk memenuhi kebutuhan bayi dalam segala hal. Menurut Ruly Andriani. ${ }^{23}$

\section{Kesimpulan}

1. Tidak ada hubungan pengetahuan ibu dengan status gizi anak balita dengan $p$ value 0,369 .

2. Tidak ada hubungan pendidikan ibu dengan status gizi anak balita dengan $p$ value 0,805 .

3. Tidak ada hubungan Pendapatan keluarga dengan status gizi anak balita dengan $p$ value 0,753 .

4. Ada hubungan pemberian ASI eksklusif dengan status gizi anak balita dengan $p$ value 0,001 .

\section{Saran}

Peningkatan keaktifan bagi orang tua balita dalam kegiatan posyandu, hal ini dapat sebagai media untuk memantau pertumbuhan balita yang dapat meningkatkan kesehatan balita

\section{Daftar Pustaka}

1. Adriani, M,dkk, B. Peran Gizi dalam siklus kehidupan. Jakarta :kencana Prenada Media Grup. 2014

2. Astuti, Turina, 2012. Hubungan Pendidikan Ibu Dengan Status Gizi anak Pra Sekolah Dan Sekolah Dasar Di Kecamatan Godean.Tersedia di http eJurnal Pustaka Kesehatan. Diakses tanggal 30 Agustus 2018

3. Rully Andriani, 2015, Hubungan Pemberian ASI Eksklusif terhadap Gizi Kurang, Tersedia dihttp://ejournals1PemberianAsiEksklusif/i ndex.php/jkm

4. Azwar., A., 2004. Aspek Kesehatan dan Gizi dalam Ketahanan Pangan dalam Widya Karya Pangan dan Gizi Nasional VIII. 17-19 Mei 2004, Jakarta

5. Depkes RI., 2002. Pemantauan Pertumbuhan Balita. Direktor Jenderal Bina Kesehatan Direktorat Gizi Masyarakat,Jakarta.

6. Depkes RI., 2008. Riset Kesehatan Dasar (Riskesdas) Badan Penelitian dan Pengembangan, Departemen Kesehatan RI, Jakarta.

7. Depkes RI., 2009. Rencana Pembangunan Jangka Panjang Bidang Kesehatan 20052025, Jakarta.

8. Hariadi, 2010. Hubungan Pendidikan Ibu Dengan Status Gizi Balita. Tersedia dihttp://ejournals1.Hubunganpendidikante rhadapstatusgizibalita.ac.id/index.php/jkm

9. Jalal, F; Soekiman., 1990. Pemanfaatan Antropmetri sebagai Indikator Sosial Ekonomi. Gizi Indonesia 1990; 14 (2):26-3

10. Kemenkes RI., 2013. Riset Kesehatan Dasar (Riskesdas) 2013. Badan Penelitian Dan Pengembangan Kesehatan Kementerian Kesehatan RI, Jakarta. 
11. Moehdji, S., 2003. Ilmu Gizi dan Penanggulangan Gizi Buruk. Papas Sinar Sinanti, Jakarta.

12. Nency, 2016. Analisis Faktor Yang Mempengaruhi Kejadian Kurang Gizi pada Anak Balita Di Provinsi Sumatra Utara.Tesis.Sekolah Pascasarjana Universitas Sumatra Utara.

13. Notoatmodjo, S. 2003. Pendidikan dan Perilaku Kesehatan. Jakarta. Rineka Cipta

14. 2010. Metodologi penelitian Kesehatan. Jakarta. Rineka Cipta

15. Puspasari, Andri, 2017, Hubungan Pendapatan Keluarga Dengan Status Gizi .Tersedia di http e-Jurnal Pustaka Kesehatan.

16. Widyastuti, M Kurnia, 2013, Hubungan Pemberian ASI Eksklusif terhadap Status gizi .Tersedia di http e-Jurnal Pustaka Kesehatan.

17. Waryana. $2010 . \quad$ Gizi Reproduksi.Yogyakarta. Pustaka Rihana.

18. Soegeng Santoso.dkk. 2009. Kesehatan Dan Gizi. Jakarta: PT. Rineka Cipta PT. Bina Adiaksara.

19. Suhardjo, 2003. Berbagai cara pendidikan gizi. Jakarta. Bumi aksara

20. Susanti, dkk,Hubungan Pengetahuan Ibu terhadap Status Gizi.Tersedia di http eJurnal Pustaka Kesehatan.

21. Kemenkes RI., 2011. Panduan Penyelenggaraan PMT Pemulihan Bagi Balita Gizi Kurang, Jakarta.

22. Rina, 2011. Hubungan Pendidikan Dengan Status Gizi Balita, tersedia Di dihttp://ejournals1.undip.ac.id/index.php/jk $m$

23. Rully Andriani, 2015, Hubungan Pemberian ASI Eksklusif terhadap Gizi Kurang,Tersedia dihttp://ejournals1PemberianAsiEksklusif/i ndex.php/jkm 